\title{
Regenerative Medicine and Biomarkers for Dilated Cardiomyopathy
}

\author{
Pierluigi Lesizza, Aneta Aleksova, Benedetta Ortis, \\ Antonio Paolo Beltrami, Mauro Giacca, \\ and Gianfranco Sinagra
}

\section{Abbreviations and Acronyms}

$\begin{array}{ll}\text { BMMNC } & \text { Bone marrow mononuclear cell } \\ \text { BNP } & \text { Brain natriuretic peptide } \\ \text { BUN } & \text { Blood urea nitrogen } \\ \text { CM } & \text { Cardiomyocyte } \\ \text { CPC } & \text { Cardiac progenitor cell } \\ \text { DCM } & \text { Dilated cardiomyopathy } \\ \text { ESC } & \text { Embryonic stem cell } \\ \text { Gal-3 } & \text { Galectin-3 } \\ \text { GDF-15 } & \text { Growth and differentiation factor-15 } \\ \text { GFR } & \text { Glomerular filtration rate } \\ \text { Hb } & \text { Haemoglobin } \\ \text { HF } & \text { Heart failure } \\ \text { hs-TnT } & \text { High-sensitivity troponin T } \\ \text { IL-1 } \beta & \text { Interleukin-1 } \beta \\ \text { iPSC } & \text { Induced pluripotent stem cell }\end{array}$

P. Lesizza $(\varangle) \cdot$ A. Aleksova $\cdot$ B. Ortis

Cardiovascular Department, Azienda Sanitaria Universitaria Integrata, University of Trieste (ASUITS), Trieste, Italy
A. P. Beltrami
Pathology Department, School of Medicine, University of Udine, Udine, Italy
e-mail: antonio.beltrami@uniud.it

\section{Giacca}
Molecular Medicine Laboratory, International Centre for Genetic Engineering and Biotechnology (ICGEB), Trieste, Italy
e-mail: giacca@icgeb.org
G. Sinagra
Cardiovascular Department, Azienda Sanitaria Universitaria Integrata, Trieste, Italy
e-mail: gianfranco.sinagra@asuits.sanita.fvg.it 


$\begin{array}{ll}\text { KCCQ } & \text { Kansas City Cardiomyopathy Questionnaire } \\ \text { KIM-1 } & \text { Kidney injury molecule-1 } \\ \text { LGE } & \text { Late gadolinium enhancement } \\ \text { LVAD } & \text { Left ventricular assist device } \\ \text { LVEF } & \text { Left ventricle ejection fraction } \\ \text { LVRR } & \text { Left ventricular reverse remodelling } \\ \text { MACE } & \text { Major adverse cardiac event } \\ \text { MLHFQ } & \text { Minnesota Living with Heart Failure Questionnaire } \\ \text { MRI } & \text { Magnetic resonance imaging } \\ \text { NPs } & \text { Natriuretic peptides } \\ \text { NT-proBNP } & \text { N-terminal pro-BNP } \\ \text { NYHA } & \text { New York Heart Association } \\ \text { SHFM } & \text { Seattle Heart Failure Model } \\ \text { SST2 } & \text { Soluble ST2 } \\ \text { TGF } & \text { Transforming growth factor } \\ \text { Tns } & \text { Troponins } \\ \text { WRF } & \text { Worsening renal function }\end{array}$

Dilated cardiomyopathy (DCM) is associated with the loss of cardiomyocytes (CMs) and with the replacement of lost CMs by non-contractile fibrous tissue.

In the past years, the inability of the heart to repair itself after damage has led to the conclusion that CMs are unable to proliferate. More recently, however, it was discovered that CMs conserve a very low proliferation rate throughout adult life [1-3]. Consequently, many strategies to enhance endogenous CM proliferation and achieve myocardial repair have been developed.

\subsection{Strategies for Heart Regeneration}

Strategies for heart regeneration and repair may be divided into two broad groups, based on either cell or gene therapy (Fig. 11.1).

\subsubsection{Cell Therapy}

Several populations of putative cardiac progenitor cells, bone marrow-derived stem cells and pluripotent stem cells have been identified in the last two decades. Generally, cardiac progenitor cells are very rare in heart tissue and heterogeneous in nature, but all identified populations have been originally reported to be able to differentiate in vitro in various cell lines, among which CMs [4]. Cardiac progenitor cells and bone marrow-derived stem cells were thought to be able to engraft in damaged tissue and proliferate and differentiate in mature CMs [5]. Based on these original findings, administration of cardiac progenitor cells or bone marrow-derived stem cells has been extensively investigated in clinical trials for the treatment of ischaemic cardiomyopathy $[5,6]$ and DCM (see below). The negative outcome of 


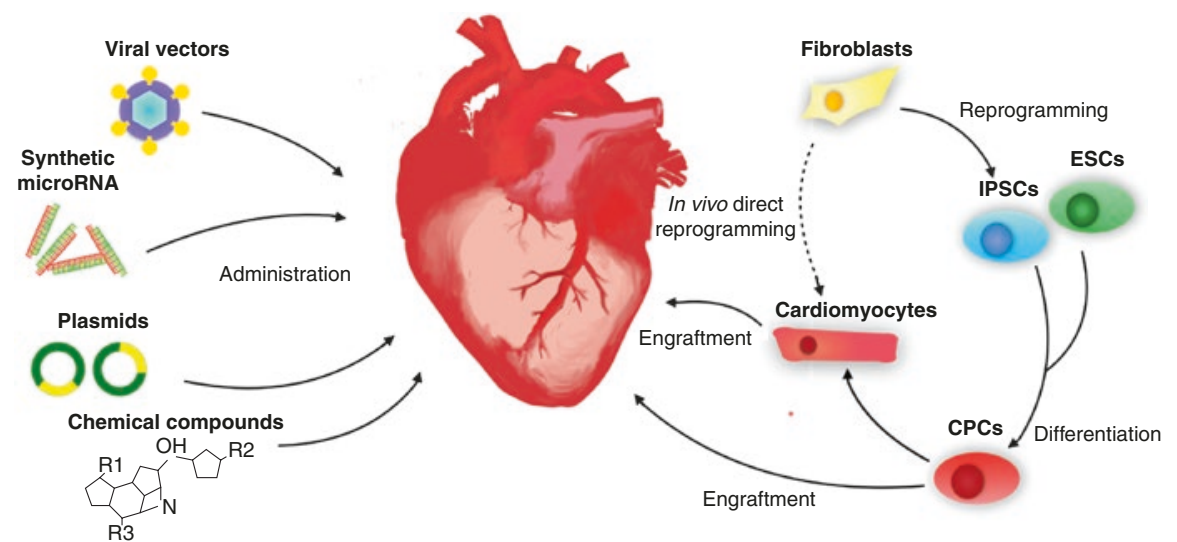

Gene therapy

Cell therapy

Fig. 11.1 Schematic representation of the strategies to enhance myocardial regeneration. On the left, strategies based on gene therapy, involving the administration of viral vectors, plasmids or synthetic RNA molecules (messenger RNA or microRNA) or the interference with specific genes using chemical compounds or microRNAs. On the right, strategies based on cell therapy, such as in vitro cardiomyocytes production from ESCs, IPSCs or CPCs and following engraftment of obtained cardiomyocytes or in vivo direct reprogramming of fibroblasts

these trials and a proper re-evaluation of the results obtained in experimental animals eventually led to the conclusion that none of these so-called stem cell populations efficiently engraft in heart tissue, proliferate and differentiate into functional CMs. The marginal beneficial effects of cell administration are mainly due to their paracrine anti-apoptotic and pro-angiogenic effect, limited by their very short persistence in vivo [7].

Another cell-based strategy involves the production and in vitro expansion of CMs from human embryonic stem cells or iPSCs [8]. The treatment in culture of these cells with an appropriate cocktail of growth factors leads to the production of relatively pure CM populations that can be injected directly as a cell suspension in the heart or grow and engraft into 3D synthetic matrices creating heart tissue patches. A major limitation in the clinical application of embryonic stem cell- and iPSC-derived CMs relates to the relative difficulty in expanding and differentiating these cells in large numbers and to the high cost needed for the their production and characterization [9]. In addition, CMs administered as a cell suspension poorly couple with native CMs, thus asynchronously contracting and potentially being arrhythmogenic [10]. The use of cardiac patches is also limited by the poor electromechanical coupling with native heart tissue and by the need of a very high amount of CMs to produce a sufficiently large cardiac patch. Improvement in these technologies is however expected in the next years; for example, Shadrin et al. [11] recently reported the production of a patch with clinically relevant dimensions $(4 \times 4 \mathrm{~cm})$.

An additional cell-based strategy is in vivo cell reprogramming. Treatment of fibroblasts in heart tissue with a cocktail of growth factors may directly induce their 
transdifferentiation in CMs. This strategy has been already applied with success in animal models, and clinical trials are awaited to confirm their efficacy in humans [12]. Principal limitations of this strategy are the low yield of conversion of fibroblasts to CMs and the need to use viral vectors as administration tools, which is fraught with low efficiency in vivo.

\subsubsection{Gene Therapy}

Gene therapy strategies aim at enhancing endogenous CM proliferation by the administration of genes encoding for proteins or non-coding RNAs. The discovery of new genes with therapeutic potential in this field mirrors the study of the mechanisms that regulate $\mathrm{CM}$ proliferation during embryonic and foetal development and the mechanism that induce CM withdrawal from proliferative state after birth [13]. With this approach, a protein, neuregulin-1 [14], and an intracellular signal transmission pathway, the Hippo pathway [15], have been identified as fundamental regulators of $\mathrm{CM}$ differentiation and proliferation during embryogenesis. Overexpression of neuregulin receptor ErbB2 and deactivation of the suppressive Hippo pathway have both been proven effective in animal models of myocardial infarction and may reach the clinical scenario as potential new therapies in a few years $[13,16]$.

In the field of gene therapy, microRNAs have been extensively studied as potential tools to induce heart regeneration due to their ability to control complex cellular processes such as proliferation, apoptosis, differentiation, migration and metabolism. Several microRNAs have been identified as regulators of CM proliferation (e.g. miR-1, miR-499, miR-133, miR-29a, miR-15 family as proliferation inhibitors and miR-17/92, miR-302/367, miR-199a-3p and miR-590-3p as proliferation activators) [17]. Some of the miRNAs have been characterized in preclinical models as potential therapeutic tools for heart regeneration, especially after myocardial infarction. Also in this case, clinical studies are warranted in the incoming years.

\subsection{Regenerative Approaches in Dilated Cardiomyopathy}

In the field of regenerative medicine, much effort has been put on the study of new therapies for ischaemic cardiomyopathy, whereas attempts to find new therapies in DCM have instead been limited [18, 19].

DCM has lagged behind in the field of regenerative medicine mostly because of its lower prevalence in comparison with ischaemic heart disease. Preclinical models of DCM are more difficult to obtain being DCM the final common phenotype of multiple pathophysiological processes, some of which even poorly understood. Moreover, the presence of regenerating cells and the extension of regenerated tissue are much easier to identify in ischaemic heart disease models, in which the necrotic tissue and scar are even macroscopically well-defined, than in DCM models, in which loss of CMs and fibrosis is diffuse. As a consequence, only a few preclinical 
studies have been conducted in models of DCM with a definite aetiology (i.e. anthracycline-induced cardiomyopathy [20] and chagasic cardiomyopathy [21]).

Despite the scarce preclinical experience in DCM, a few clinical trials have been conducted to assess the effect of putative stem cell administration in non-ischaemic DCM.

The DCM branch of MiHeart trial has been the first, and to date only, multicentre, double-blinded, placebo-controlled phase I-II trial testing the efficacy of bone marrow-derived mononuclear cells (BMMNCs) in patients affected by nonischaemic DCM [22]. Subjects enrolled had a previous diagnosis of heart failure, heart failure symptoms for at least 1 year, a diagnosis of non-ischaemic DCM according to the World Health Organization criteria, LVEF $<35 \%$ and NYHA class III or IV and were on optimal medical therapy for at least 4 weeks before randomization and throughout the study. One hundred sixteen patients were enrolled and randomized (1:1) to intracoronary injection of BMMNCs or placebo injection. The treatment proved safe, but at 12 months of follow-up, there were no statistically significant differences with regard to LVEF, MLHFQ score, 6-min walk test, VO2 max or NYHA classification. Thus, the investigators concluded that BMMNCs do not have a beneficial effect in the setting of DCM. This is most likely related to the wrong assumption that the administered cells had a true regenerative potential.

Other smaller studies have been conducted to assess the efficacy of stem cell treatment in the setting of DCM.

The first proof-of-concept study in this field was TOPCARE-DCM, a cohort study enrolling 33 patients affected by DCM with LVEF $\leq 40 \%$ and NYHA class I-III [23]. All patients underwent intracoronary infusion of BMMNCs, and investigators reported a mean improvement in LVEF at 3 months of 3.2\% as assessed by echocardiography. It has to be underlined that this is a single-centre, nonrandomized, prospective cohort study.

Vrtovec et al. reported in three different studies [24-26] that treatment with CD34+ cells led to significant improvement in global ejection fraction and in 1-year mortality. Nevertheless, all these studies enrolled a small cohort of patients, were performed at a single centre, were not double-blind nor placebo-controlled and were not powered to test for mortality.

The Autologous Bone Marrow Cells in DCM (ABCD) trial enrolled 84 patients with non-ischaemic DCM, LVEF $\leq 35 \%$ and NYHA class $\geq$ II that were randomized to intracoronary infusion of BMMNCs or optimal medical therapy [27]. At 3-year follow-up investigators reported a mean improvement in ejection fraction of $5.9 \%$ in the treated group with a significant difference between treated and control group in LVEF, left ventricle end-diastolic volume and KCCQ functional status and clinical summary score.

The INTRACELL study randomized 30 patients affected by non-ischaemic DCM, LVEF $\leq 35 \%$ and NYHA class III or IV to intramyocardial injection of BMMNCs or optimal medical therapy, but at follow-up there was no improvement in LVEF [28].

The IMPACT-DCM/Catheter-DCM enrolled both patients affected by ischaemic and non-ischaemic DCM (29 patients with non-ischaemic DCM) and randomized 
them to transendocardial injections with BMMNCs enriched in mesenchymal stromal cells and M2-like macrophages or to optimal medical therapy [29]. After 1 year of follow-up, there were no significant differences between control and treated group in terms of LVEF and functional status.

Taken together, the data from these experimentations, most of which were small, single-centre and non-blinded, indicate that the eventual benefit provided by administration of bone marrow mononuclear cells is marginal at best and most likely related to the paracrine effect of these cells rather than to their regenerative potential [30].

As a consequence, regenerative approaches to heal the heart, both in the ischaemic and non-ischaemic settings, are now moving from stem cell therapies to gene therapy, which presents with a much more relevant preclinical background, holding high promise, even though still far from extensive clinical application.

\subsection{Biomarkers and Dilated Cardiomyopathy}

Idiopathic DCM is a primary myocardial disease characterized by progressive left ventricular o biventricular dilatation and dysfunction, presenting with different degrees of $\mathrm{HF}$, ranging from asymptomatic dysfunction to advanced HF with refractory symptoms, which often requires heart transplantation. Patients with idiopathic DCM are younger than those with ischaemic cardiomyopathy, have fewer comorbidities and have a longer life expectancy. For this reason, prognostic assessment is particularly important for these patients.

In the last years, the advances in the comprehension of HF pathophysiology led to the identification of several molecules that act as biomarkers and are representative of HF complex biological mechanisms, such as inflammation, oxidative stress and neurohormonal activation. Biomarkers may help clinicians in diagnosing, assessing severity and especially predicting prognosis of HF. The term biomarker was defined in 2001 by the Biomarkers Definition Working Group of the National Institutes of Health [31] as "a characteristic that is objectively measured and evaluated as an indicator of normal biological processes, pathogenic processes, or pharmacologic responses to a therapeutic intervention". Focusing on laboratory biomarkers, Prof. Braunwald identified seven main categories, corresponding to an equal number of pathobiological processes occurring in HF: myocardial stretch, inflammation, matrix remodelling, myocyte injury, renal dysfunction, neurohumoral activation and oxidative stress [32].

The most widely used biomarkers in patients suffering from HF are natriuretic peptides. BNP and NT-proBNP are secreted in response to the stretching of atrial and ventricular walls and are recommended tools for the diagnosis of HF, according to the latest ESC guidelines [33]. Accordingly, the evaluation of their plasmatic concentration on hospital admission is predictive of outcome in patients with acute $\mathrm{HF}$, and their increase despite optimized therapy in chronic HF predicts morbidity and mortality [34]. Moreover, in the setting of acute decompensated HF, the occurrence of WRF with a significant decrease of BNP is a marker of adequate decongestion and favourable outcome [35]. Few studies investigated the role of natriuretic 
peptides in the peculiar setting of idiopathic DCM. BNP was correlated to clinical severity of HF and congestion [36], and NT-proBNP correlated with LVEF, NYHA class and mortality [37], identifying patients with a more severe HF, and it was the best predictor of long-term LVRR, which by itself is a predictor of favourable outcomes [38].

Inflammation and matrix remodelling, expressed as fibrosis, are two pathobiological processes involved in systolic and diastolic dysfunction, leading to cardiac remodelling and overt heart failure. Gal-3 is a lectin secreted by activated macrophages that favours the development of cardiac fibrosis via fibroblast stimulation [39] and represents the link between inflammation and fibrosis. Gal-3 already showed to have a prognostic role in patients affected by HF: the higher the levels, the more severe the cardiac fibrosis and left ventricular remodelling [40]. In the setting of chronic HF, values of plasmatic Gal-3 above $17.8 \mathrm{ng} / \mathrm{mL}$ predict an unfavourable outcome in terms of hospitalization and mortality [41, 42]. However, Gal-3 is not a heart-specific biomarker and is abundantly expressed in many organs and tissues, and its values are influenced also by comorbid conditions such as diabetes and renal or liver dysfunction [40]. With specific regard to idiopathic DCM, Besler et al. showed that Gal-3 myocardial expression directly correlates with the extent of histologically assessed cardiac fibrosis [43]. Additionally, in this peculiar setting, Gal-3 maintains its predictive power. Indeed, in two independent studies, Gal-3 was compared with LGE presence at cardiac MRI in idiopathic DCM patients. Gal-3 plasma levels represented the extent of fibrosis at MRI [44], and both Gal-3 and LGE presence significantly predicted MACEs in DCM, especially when the two are combined [45]. Another biomarker of inflammation and fibrosis is SST2, a member of the interleukin (IL)-1 receptor-like family, that is secreted in response to myocardial strain and IL1 stimulation [46]. sST2, acting as a decoy receptor, reduces the cardioprotective effects of IL-33. High sST2 values are predictors of short- and long-term mortality in chronic HF [47]. Ky et al. demonstrated that patients with sST2 higher than $36.6 \mathrm{ng} / \mathrm{mL}$ have a three times higher risk of death or cardiac transplantation than those with lower values [48]. When compared to other biomarkers, sST2 is superior to Gal-3 and NT-proBNP in risk stratification [39], being the best predictor of cardiovascular mortality. These results are particularly interesting, because sST2 levels are not significantly influenced by other conditions, such as renal dysfunction or obesity [49]. Moreover, the increase over time of sST2 levels is predictive of disease progression in HF [50] and could identify patients with a more severe fibrosis. Lupon et al. developed the ST2-R2 score to predict reverse remodelling in HF with systolic dysfunction; patients with sST2 values above $48 \mathrm{ng} / \mathrm{mL}$ will unlikely experience LVRR [51]. These findings are confirmed in idiopathic DCM stable patients: Wojciechowska et al. demonstrated that sST2 correlates with all-cause mortality and the combined outcome of death, cardiac transplantation and LVAD implantation, in particular when assessing serial changes in sST2 values [52].

Besides Gal-3 and sST2, the inflammatory and fibrotic processes are also mirrored by elevation of interleukin and growth factor levels, which can therefore be employed as useful biomarkers for prognostic stratification. The activation of the 
inflammasome drives the inflammatory response that promotes cardiac remodelling and heart failure [53]. This process can be detected dosing circulating interleukins. In idiopathic DCM patients, IL-1 $\beta$ showed to be a highly significant long-term predictor of death or cardiac transplantation [54].

GDF-15 belongs to the TGF family and is involved in inflammation, fibrosis and ventricular remodelling [55]. In idiopathic DCM patients, it correlates with symptoms severity, BNP and sST2 levels and grade of systolic dysfunction. Stojkovic et al. demonstrated that GDF-15 is able to predict not only all-cause mortality, but also arrhythmic deaths, which are a not negligible cause of mortality in idiopathic DCM patients. GDF-15 levels above $884 \mathrm{pg} / \mathrm{mL}$ conferred a two times higher risk of arrhythmic death or resuscitated cardiac arrest and a three times higher risk of all-cause mortality, predicting the outcome with a higher accuracy than ST2 [56].

Troponins are well-known markers of myocardial injury. In the setting of HF, high values of troponin I or T predict a worse grade of left ventricular dysfunction and a higher risk of death [40]. In a study by Kawahara et al., hs-TnT value above $0.01 \mathrm{ng} / \mathrm{mL}$ reflected the degree of myocardial damage and was an independent predictor of mortality, especially when combined with left ventricular dysfunction. The result was conserved even in the cohort of patients with chronic HF caused by idiopathic DCM patients [57].

Besides laboratory biomarkers, also clinical variables are important in defining prognosis in HF in clinically stable idiopathic DCM patients. Aleksova et al. demonstrated that anaemia, defined as haemoglobin concentration lower than $13 \mathrm{~g} / \mathrm{dL}$ in men and $12 \mathrm{~g} / \mathrm{dL}$ in women, was a predictor of unfavourable outcomes. Moreover, the new onset of anaemia was as well an independent predictor of poor outcome, leading to a doubled risk of death or heart transplantation [58].

Renal failure is as well-known prognostically relevant complication occurring in HF patients. Consistently, creatinine, BUN and estimated GFR are independent predictors of prognosis [40]. However, WRF occurs frequently during uptitration of diuretic treatment in case of clinical congestion and is not necessarily related to poor outcomes [35]. In idiopathic DCM, renal failure occurs in $20 \%$ of patients during the first 8 years after diagnosis, up to $50 \%$ at 20-year follow-up [59]. In these patients, a GFR between 30 and $60 \mathrm{~mL} / \mathrm{min} / 1.73 \mathrm{~m}^{2}$ nearly triplicates the risk for cardiac events [60]. NGAL and KIM-1 are useful biomarkers in early detection of WRF, even before the decline in GFR. When used in HF patients, they are also predictors of all-cause mortality and hospital admission [61].

In clinical practice, biomarkers are widely used to better characterize patients with HF and are useful tools in predicting prognosis (Fig. 11.2). The wide spectrum of pathophysiological processes explored by the amount of available biomarkers and the specific characteristics of each one make them advantageous especially when used in combination. The additive value of a multimarker approach in HF has been largely investigated in literature. Pascual-Figal et al. stratified acutely decompensated HF patients using sST2, NT-proBNP and hs-TnT: patients with all three biomarkers elevated had $50 \%$ of risk of death, compared to $0 \%$ of risk in those with none elevated [62]. Ky et al. identified eight biomarkers ameliorating risk 


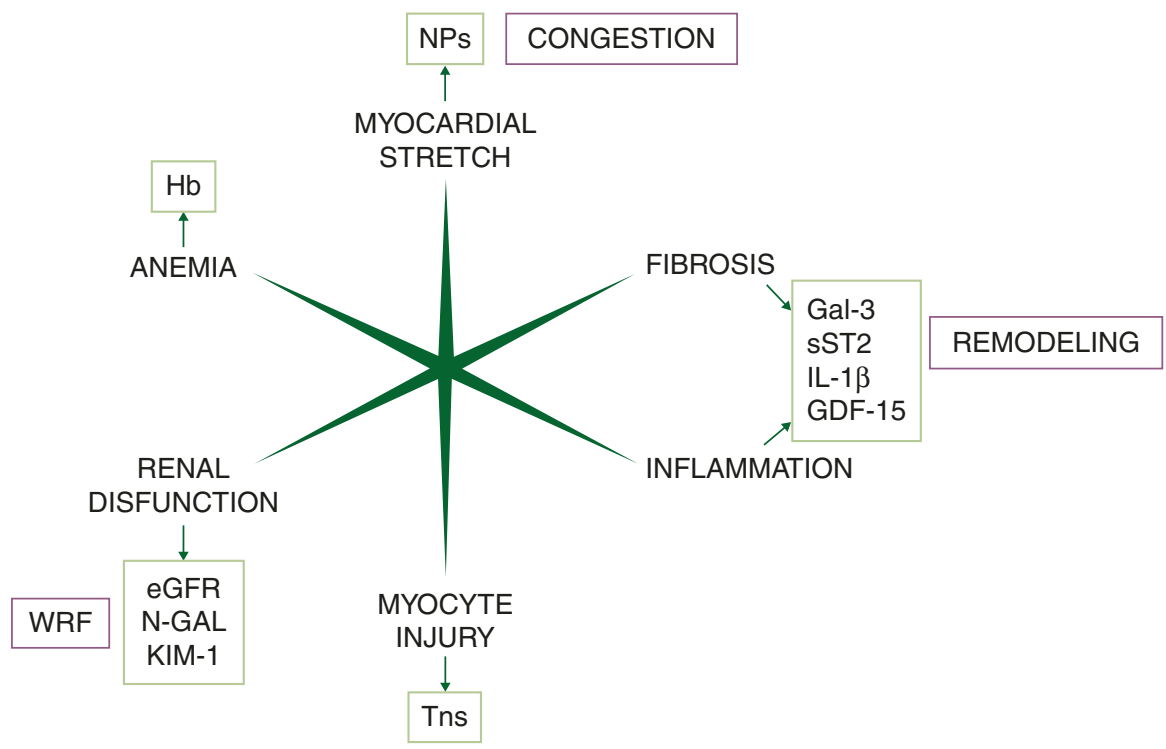

Fig. 11.2 Overview of biomarker classification and their significance in DCM

stratification in addition to the SHFM, a validated risk score in HF patients. They identified three classes of risk: low, intermediate and high; the latter two had, respectively, 4.7- and 13.3-fold increase of risk of adverse outcomes [63]. Lupon et al. developed a risk calculator (BCN Bio-HF) incorporating NT-proBNP, hs-TnT, sST2 and clinical variables; when biomarkers levels were added, a better risk classification in individual prediction of death was achieved [64].

In conclusion, a multimarker strategy is able to characterize every patient identifying those with more fibrotic, inflammatory or ischaemic elements. Multimarker strategy gives a deeper insight in HF pathophysiology and, above all, is needed for a tailored diagnostic and therapeutic strategy based on each patient's characteristics.

\section{References}

1. Bergmann O, Bhardwaj RD, Bernard S, Zdunek S, Barnabé-Heider F, Walsh S, et al. Evidence for cardiomyocyte renewal in humans. Science. 2009;324(5923):98-102. https://doi. org/10.1126/science.1164680.

2. Bergmann O, Zdunek S, Felker A, Salehpour M, Alkass K, Bernard S, et al. Dynamics of cell generation and turnover in the human heart. Cell. 2015;161(7):1566-75. https://doi. org/10.1016/j.cell.2015.05.026.

3. Senyo SE, Steinhauser ML, Pizzimenti CL, Yang VK, Cai L, Wang M, et al. Mammalian heart renewal by pre-existing cardiomyocytes. Nature. 2013;493(7432):433-6. https://doi. org/10.1038/nature11682.

4. Santini MP, Forte E, Harvey RP, Kovacic JC. Developmental origin and lineage plasticity of endogenous cardiac stem cells. Development. 2016;143(8):1242-58. https://doi.org/10.1242/ dev.111591. 
5. Bolli R, Chugh AR, D'Amario D, Loughran JH, Stoddard MF, Ikram S, et al. Cardiac stem cells in patients with ischaemic cardiomyopathy (SCIPIO): initial results of a randomised phase 1 trial. Lancet. 2011;378(9806):1847-57. https://doi.org/10.1016/S0140-6736(11)61590-0.

6. Keith MC, Bolli R. "String theory" of c-kit(pos) cardiac cells: a new paradigm regarding the nature of these cells that may reconcile apparently discrepant results. Circ Res. 2015;116(7):1216-30. https://doi.org/10.1161/CIRCRESAHA.116.305557.

7. Lin Z, Pu WT. Strategies for cardiac regeneration and repair. Sci Transl Med. 2014;6(239):239rv1. https://doi.org/10.1126/scitranslmed.3006681.

8. Takahashi K, Yamanaka S. Induction of pluripotent stem cells from mouse embryonic and adult fibroblast cultures by defined factors. Cell. 2006;126(4):663-76. https://doi.org/10.1016/j. cell.2006.07.024.

9. Laflamme MA, Murry CE. Heart regeneration. Nature. 2011;473(7347):326-35. https://doi. org/10.1038/nature10147.

10. Chong JJ, Yang X, Don CW, Minami E, Liu YW, Weyers JJ, et al. Human embryonic-stem-cellderived cardiomyocytes regenerate non-human primate hearts. Nature. 2014;510(7504):2737. https://doi.org/10.1038/nature13233.

11. Shadrin IY, Allen BW, Qian Y, Jackman CP, Carlson AL, et al. Cardiopatch platform enables maturation and scale-up of human pluripotent stem cell-derived engineered heart tissues. Nat Commun. 2017;8(1):1825. https://doi.org/10.1038/s41467-017-01946-x.

12. Srivastava D, DeWitt N. In vivo cellular reprogramming: the next generation. Cell. 2016;166(6):1386-96. https://doi.org/10.1016/j.cell.2016.08.055.

13. Uygur A, Lee RT. Mechanisms of cardiac regeneration. Dev Cell. 2016;36(4):362-74. https:// doi.org/10.1016/j.devcel.2016.01.018.

14. Polizzotti BD, Ganapathy B, Walsh S, Choudhury S, Ammanamanchi N, Bennett DG, et al. Neuregulin stimulation of cardiomyocyte regeneration in mice and human myocardium reveals a therapeutic window. Sci Transl Med. 2015;7(281):281ra45. https://doi.org/10.1126/ scitranslmed.aaa5171.

15. Heallen T, Zhang M, Wang J, Bonilla-Claudio M, Klysik E, Johnson RL, et al. Hippo pathway inhibits Wnt signaling to restrain cardiomyocyte proliferation and heart size. Science. 2011;332(6028):458-61. https://doi.org/10.1126/science.1199010.

16. D’Uva G, Aharonov A, Lauriola M, Kain D, Yahalom-Ronen Y, Carvalho S, et al. ERBB2 triggers mammalian heart regeneration by promoting cardiomyocyte dedifferentiation and proliferation. Nat Cell Biol. 2015;17(5):627-38. https://doi.org/10.1038/ncb3149.

17. Giacca M, Zacchigna S. Harnessing the microRNA pathway for cardiac regeneration. J Mol Cell Cardiol. 2015;89(Pt A):68-74. https://doi.org/10.1016/j.yjmcc.2015.09.017.

18. McNally EM, Mestroni L. Dilated cardiomyopathy: genetic determinants and mechanisms. Circ Res. 2017;121(7):731-48. https://doi.org/10.1161/CIRCRESAHA.

19. Bolli R, Ghafghazi S. Current status of cell therapy for non-ischaemic cardiomyopathy: a brief overview. Eur Heart J. 2015;36(42):2905-8. https://doi.org/10.1093/eurheartj/ehv454.

20. Psaltis PJ, Carbone A, Nelson AJ, Lau DH, Jantzen T, Manavis J, et al. Reparative effects of allogeneic mesenchymal precursor cells delivered transendocardially in experimental nonischemic cardiomyopathy. JACC Cardiovasc Interv. 2010;3(9):974-83. https://doi.org/10.1016/j. jcin.2010.05.016.

21. Guarita-Souza LC, Carvalho KA, Woitowicz V, Rebelatto C, Senegaglia A, Hansen P, et al. Simultaneous autologous transplantation of cocultured mesenchymal stem cells and skeletal myoblasts improves ventricular function in a murine model of Chagas disease. Circulation. 2006;114(1 Suppl):I120-4. https://doi.org/10.1161/CIRCULATIONAHA.105.000646.

22. Martino H, Brofman P, Greco O, Bueno R, Bodanese L, Clausell N, et al.; Dilated Cardiomyopathy Arm of the MiHeart Study Investigators. Multicentre, randomized, double-blind trial of intracoronary autologous mononuclear bone marrow cell injection in non-ischaemic dilated cardiomyopathy (the dilated cardiomyopathy arm of the MiHeart study). Eur Heart J. 2015;36(42):2898-904. https://doi.org/10.1093/eurheartj/ehv477.

23. Fischer-Rasokat U, Assmus B, Seeger FH, Honold J, Leistner D, Fichtlscherer S, et al. A pilot trial to assess potential effects of selective intracoronary bone marrow-derived progeni- 
tor cell infusion in patients with nonischemic dilated cardiomyopathy: final 1-year results of the transplantation of progenitor cells and functional regeneration enhancement pilot trial in patients with nonischemic dilated cardiomyopathy. Circ Heart Fail. 2009;2(5):417-23. https:// doi.org/10.1161/CIRCHEARTFAILURE.109.855023.

24. Vrtovec B, Poglajen G, Sever M, Lezaic L, Domanovic D, Cernelc P, et al. Effects of intracoronary stem cell transplantation in patients with dilated cardiomyopathy. J Card Fail. 2011;17(4):272-81. https://doi.org/10.1016/j.cardfail.2010.11.007.

25. Vrtovec B, Poglajen G, Lezaic L, Sever M, Domanovic D, Cernelc P, et al. Effects of intracoronary $\mathrm{CD} 34+$ stem cell transplantation in nonischemic dilated cardiomyopathy patients: 5-year follow-up. Circ Res. 2013;112(1):165-73. https://doi.org/10.1161/ CIRCRESAHA.112.276519.

26. Vrtovec B, Poglajen G, Lezaic L, Sever M, Socan A, Domanovic D, et al. Comparison of transendocardial and intracoronary $\mathrm{CD} 34+$ cell transplantation in patients with nonischemic dilated cardiomyopathy. Circulation. 2013;128(11 Suppl 1):S42-9. https://doi.org/10.1161/ CIRCULATIONAHA.112.000230.

27. Seth S, Bhargava B, Narang R, Ray R, Mohanty S, Gulati G, et al. The ABCD (autologous bone marrow cells in dilated cardiomyopathy) trial a long-term follow-up study. J Am Coll Cardiol. 2010;55(15):1643-4. https://doi.org/10.1016/j.jacc.2009.11.070.

28. Sant'Anna RT, Fracasso J, Valle FH, Castro I, Nardi NB, et al. Direct intramyocardial transthoracic transplantation of bone marrow mononuclear cells for non-ischemic dilated cardiomyopathy: INTRACELL, a prospective randomized controlled trial. Rev Bras Cir Cardiovasc. 2014;29(3):437-47. https://doi.org/10.5935/1678-9741.20140091.

29. Henry TD, Traverse JH, Hammon BL, East CA, Bruckner B, Remmers AE, et al. Safety and efficacy of ixmyelocel-T: an expanded, autologous multi-cellular therapy, in dilated cardiomyopathy. Circ Res. 2014;115(8):730-7. https://doi.org/10.1161/CIRCRESAHA.115.304554.

30. Menasché $P$. Cell therapy trials for heart regeneration-lessons learned and future directions. Nat Rev Cardiol. 2018;15(11):659-71. https://doi.org/10.1038/s41569-018-0013-0.

31. Biomarkers Definition Working Group. Biomarkers and surrogate endpoints: preferred definitions and conceptual framework. Clin Pharmacol Ther. 2001;69:89-95. https://doi. org/10.1067/mcp.2001.113989.

32. Braunwald E. Biomarkers in heart failure. N Engl J Med. 2008;358:2148-59. https://doi. org/10.1056/NEJMra0800239.

33. Ponikowski P, Voors AA, Anker SD, Bueno H, Cleland JGF, Coats AJS, et al. 2016 ESC guidelines for the diagnosis and treatment of acute and chronic heart failure: the task force for the diagnosis and treatment of acute and chronic heart failure of the European Society of Cardiology (ESC). Eur Heart J. 2016;37:2129-200. https://doi.org/10.1093/eurheartj/ehw128.

34. Phreaner N, Shah K, Maisel A. Natriuretic peptides and biomarkers in the diagnosis of heart failure. In: Jagadesh G, Balakumar P, Maung UK, editors. Pathophysiology and pharmacotherapy of cardiovascular disease. Switzerland: Springer International Publishing AG; 2015. https://doi.org/10.1007/978-3-319-15961-4_12.

35. Stolfo D, Stenner E, Merlo M, Porto AG, Moras C, Barbati G, et al. Prognostic impact of BNP variations in patients admitted for acute decompensated heart failure with in hospital worsening renal function. Heart Lung Circ. 2017;26(3):226-34. https://doi.org/10.1016/j. hlc.2016.06.1205.

36. Amorim S, Campelo M, Moura B, Martins E, Rodrigues J, Barroso I, et al. The role of biomarkers in dilated cardiomyopathy: assessment of clinical severity and reverse remodeling. Rev Port Cardiol. 2017;36(10):709-16. https://doi.org/10.1016/j.repc.2017.02.015.

37. Bielecka-Dabrowa A, von Haehling S, Aronow WS, Ahmed MI, Rysz J, Banach M. Heart failure biomarkers in patients with dilated cardiomyopathy. Int J Cardiol. 2013;168(3):2404-10. https://doi.org/10.1016/j.ijcard.2013.01.157.

38. Merlo M, Pyxaras SA, Pinamonti B, Barbati G, Di Lenarda A, Sinagra G. Prevalence and prognostic significance of left ventricular reverse remodeling in dilated cardiomyopathy receiving tailored medical treatment. J Am Coll Cardiol. 2011;57:1468-76. https://doi.org/10.1016/j. jacc.2010.11.030. 
39. Bayes-Genis A, de Antonio M, Vila J, Peñafiel J, Galán A, Barallat J. Head-to-head comparison of 2 myocardial fibrosis biomarkers for long-term heart failure risk stratification: ST2 versus galectin-3. J Am Coll Cardiol. 2014;63(2):158-66. https://doi.org/10.1016/j.jacc.2013.07.087.

40. Correale M, Monaco I, Brunetti ND, Di Biase M, Metra M, Nodari S, et al. Redefining biomarkers for heart failure. Heart Fail Rev. 2018;23(2):237-53. https://doi.org/10.1007/ s10741-018-9683-2.

41. Lok DJ, Van Der Meer P, de la Porte PW, Lipsic E, Van Wijngaarden J, Hillege HL, et al. Prognostic value of galectin-3, a novel marker of fibrosis, in patients with chronic heart failure: data from the DEAL-HF study. Clin Res Cardiol. 2010;99(5):323-8. https://doi.org/10.1007/ s00392-010-0125-y.

42. Meijers WC, Januzzi JL, de Filippi C, Adourian AS, Shah SJ, van Veldhuisen DJ, et al. Elevated plasma galectin-3 is associated with near-term rehospitalization in heart failure: a pooled analysis of 3 clinical trials. Am Heart J. 2014;167(6):853-60.e4. https://doi.org/10.1016/j. ahj.2014.02.011.

43. Besler C, Lang D, Urban D, Rommel KP, von Roeder M, Fengler K, et al. Plasma and cardiac galectin-3 in patients with heart failure reflects both inflammation and fibrosis. Circ Heart Fail. 2017;10(3). pii: e003804. https://doi.org/10.1161/CIRCHEARTFAILURE.116.003804.

44. Vergaro G, Del Franco A, Giannoni A, Prontera C, Ripoli A, Barison A, et al. Galectin-3 and myocardial fibrosis in nonischemic dilated cardiomyopathy. Int J Cardiol. 2015;184:96-100. https://doi.org/10.1016/j.ijcard.2015.02.008.

45. Hu DJ, Xu J, Du W, Zhang JX, Zhong M, Zhou YN. Cardiac magnetic resonance and galectin3 level as predictors of prognostic outcomes for non-ischemic cardyomyopathy patients. Int $\mathrm{J}$ Cardiovasc Imaging. 2016;32(12):1725-33. https://doi.org/10.1007/s10554-016-0958-1.

46. Kakkar R, Lee RT. The IL-33/ST2 pathway: therapeutic target and novel biomarker. Nat Rev Drug Discov. 2008;7(10):827-40. https://doi.org/10.1038/nrd2660.

47. Felker GM, Fiuzat M, Thompson V, Shaw LK, Neely ML, Adams KF, et al. Soluble ST2 in ambulatory patients with heart failure: association with functional capacity and long-term outcomes. Circ Heart Fail. 2013;6(6):1172-9. https://doi.org/10.1161/ CIRCHEARTFAILURE.113.000207.

48. Ky B, French B, McCloskey K, Rame JE, McIntosh E, Shahi P, et al. High-sensitivity ST2 for prediction of adverse outcomes in chronic heart failure. Circ Heart Fail. 2011;4(2):180-7. https://doi.org/10.1161/CIRCHEARTFAILURE.110.958223.

49. Mallick A, Januzzi JL Jr. Biomarkers in acute heart failure. Rev Esp Cardiol (Engl Ed). 2015;68(6):514-25. https://doi.org/10.1016/j.rec.2015.02.009.

50. Wu AH, Wians F, Jaffe A. Biological variation of galectin-3 and soluble ST2 for chronic heart failure: implication on interpretation of test results. Am Heart J. 2013;165(6):995-9. https:// doi.org/10.1016/j.ahj.2013.02.029.

51. Lupón J, Gaggin HK, de Antonio M, Domingo M, Galán A, Zamora E, et al. Biomarkerassist score for reverse remodelling prediction in heart failure: the ST2-R2 score. Int J Cardiol. 2015;184:337-43. https://doi.org/10.1016/j.ijcard.2015.02.019.

52. Wojciechowska C, Romuk E, Nowalany-Kozielska E, Jacheć W. Serum galectin-3 and ST2 as predictors of unfavourable outcome in stable dilated cardiomyopathy patients. Hellenic $\mathrm{J}$ Cardiol. 2017;58(5):350-9. https://doi.org/10.1016/j.hjc.2017.03.006.

53. Toldo S, Mezzaroma E, Mauro AG, Salloum F, Van Tassell BW, Abbate A. The inflammasome in myocardial injury and cardiac remodelling. Antioxid Redox Signal. 2015;22:1146-61. https://doi.org/10.1089/ars.2014.5989.

54. Aleksova A, Beltrami AP, Carriere C, Barbati G, Lesizza P, Perrieri-Montanino M, et al. Interleukin- $1 \beta$ levels predict long-term mortality and need for heart transplantation in ambulatory patients affected by idiopathic dilated cardiomyopathy. Oncotarget. 2017;8(15):2513140. https://doi.org/10.18632/oncotarget.15349.

55. Nair N, Gongora E. Correlations of GDF-15 with sST2, MMPs, and worsening functional capacity in idiopathic dilated cardiomyopathy: can we gain new insights into the pathophysiology? J Circ Biomark. 2018;7:1-8. https://doi.org/10.1177/1849454417751735. 
56. Stojkovic S, Kaider A, Koller L, Brekalo M, Wojta J, Diedrich A, et al. GDF-15 is a better complimentary marker for risk stratification of arrhythmic death in non-ischemic, dilated cardiomyopathy than soluble ST2. J Cell Mol Med. 2018;22(4):2422-9. https://doi.org/10.1111/ jcmm.13540.

57. Kawahara C, Tsutamoto T, Nishiyama K, Yamaji M, Sakai H, Fujii M, et al. Prognostic role of high-sensitivity cardiac troponin $\mathrm{T}$ in patients with nonischemic dilated cardyomyopathy. Circ J. 2011;75(3):656-61. https://doi.org/10.1253/circj.CJ-10-0837.

58. Aleksova A, Barbati G, Merlo M, Stolfo D, Sabbadini G, Di Lenarda A, et al. Deleterious impact of mild anemia on survival of young adult patients (age $45+-14$ years) with idiopathic dilated cardiomyopathy: data from the Trieste Cardiomyopathies Registry. Heart Lung. 2011;40(5):454-61. https://doi.org/10.1016/j.hrtlng.2010.06.001.

59. Tanaka K, Ito M, Kodama M, Maruyama H, Hoyano M, Mitsuma W, et al. Longitudinal change in renal function in patients with idiopathic dilated cardiomyopathy without renal insufficiency at initial diagnosis. Circ J. 2007;71(12):1927-31. https://doi.org/10.1253/circj.71.1927.

60. Ohshima K, Hirashiki A, Cheng XW, Hayashi M, Hayashi D, Okumura T, et al. Impact of mild to moderate renal dysfunction on left ventricular relaxation function and prognosis in ambulatory patients with nonischemic dilated cardiomyopathy. Int Heart J. 2011;52(6):366-71. https://doi.org/10.1536/ihj.52.366.

61. Latini R, Aleksova A, Masson S. Novel biomarkers and therapies in cardiorenal syndrome. Curr Opin Pharmacol. 2016;27:56-61. https://doi.org/10.1016/j.coph.2016.01.010.

62. Pascual-Figal DA, Manzano-Fernández S, Boronat M, Casas T, Garrido IP, Bonaque JC, et al. Soluble ST2, high-sensitivity troponin T and N-terminal pro-B-type natriuretic peptide: complementary role for risk stratification in acutely decompensated heart failure. Eur J Heart Fail. 2011;13(7):718-25. https://doi.org/10.1093/eurjhf/hfr047.

63. Ky B, French B, Levy WC, Sweitzer NK, Fang JC, Wu AH, et al. Multiple biomarkers for risk prediction in chronic heart failure. Circ Heart Fail. 2012;5(2):183-90. https://doi.org/10.1161/ CIRCHEARTFAILURE.111.965020.

64. Lupòn J, De Antonio M, Vila J, Peñafiel J, Galán A, Zamora E, et al. Development of a novel heart failure risk tool: the Barcelona bio-heart failure risk calculator (BCN bio-HF calculator). PLoS One. 2014;9:e85466. https://doi.org/10.1371/journal.pone.0085466.

Open Access This chapter is licensed under the terms of the Creative Commons Attribution 4.0 International License (http://creativecommons.org/licenses/by/4.0/), which permits use, sharing, adaptation, distribution and reproduction in any medium or format, as long as you give appropriate credit to the original author(s) and the source, provide a link to the Creative Commons license and indicate if changes were made.

The images or other third party material in this chapter are included in the chapter's Creative Commons license, unless indicated otherwise in a credit line to the material. If material is not included in the chapter's Creative Commons license and your intended use is not permitted by statutory regulation or exceeds the permitted use, you will need to obtain permission directly from the copyright holder.

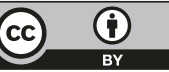

